ORIGINAL RESEARCH ARTICLE

\title{
Impacts of coal mine water and Damodar River water irrigation on soil and maize (Zea mays L.) in a coalfield area of Damodar Valley, India
}

\author{
Mukesh Kumar Mahato ${ }^{*}$, Abhay Kumar Singh ${ }^{1}$, Gurdeep Singh ${ }^{2}$ and Lalan Prasad Mishra ${ }^{3}$ \\ ${ }^{1}$ Environmental Assessment and Remediation Section, CSIR- Central institute of Mining and Fuel Research, Dhanbad-826015, \\ (Jharkhand), INDIA \\ ${ }^{2}$ Department of Environmental Science \& Engineering, IIT (Indian School of Mines), Dhanbad-826004, (Jharkhand), INDIA \\ ${ }^{3}$ P.G. Department of Chemistry, Vinoba Bhave University, Hazaribag-825301, (Jharkhand), INDIA \\ *Corresponding author's E-mail: catchmukesh8317@gmail.com
}

\section{ARTICLE HISTORY}

Received: 24 October 2017

Revised received: 10 November 2017

Accepted: 25 November 2017

Keywords

Coal mine water

Damodar River water

Irrigation

Chlorophyll

Maize (Zea mays L.)

Soil health

\begin{abstract}
The present investigation was carried out to assess the environmental and biochemical impacts due to irrigation of coal mine water and Damodar River water on Kharif crop, maize (Zea mays L.) in a coalfield area of Damodar Valley, India. Coal mine water and Damodar River water samples were collected for the monitoring of its quality from a coalfield area of Damodar Valley. The samples were analyzed for various parameters and compared with prescribed standard, which revealed that the total suspended solids of coal mine water were higher as Damodar River water. A pot experiment with $Z$. mays was conducted to study the suitability of this coal mine water for irrigation. The plants of $Z$. mays in the pots were irrigated with coal mine water and Damodar River water in two concentrations ( $100 \%$ and $50 \%$ dilution with double distilled water) and pure double distilled water was used for control. There was $100 \%$ germination of $Z$. mays in all the treatments. The plant growth, chlorophyll content of $Z$. mays and soil quality parameters were significantly better in coal mine water and Damodar River water treated pots. However, the Damodar River water and coal mine water could be successfully used for irrigation. In general, coal mine water and Damodar River water can be used after mixing with good quality of water has shown better growth of $Z$. mays.
\end{abstract}

C2017 Agriculture and Environmental Science Academy

Citation of this article: Mahato, M.K., Singh, A.K., Singh, G. and Mishra, L.P. (2017). Impacts of coal mine water and Damodar River water irrigation on soil and maize (Zea mays L.) in a coalfield area of Damodar Valley, India. Archives of Agriculture and Environmental Science, 2 (4): 293-297, DOI: $10.26832 / 24566632.2017 .020407$

\section{INTRODUCTION}

The coal mine water (CMW) can vary greatly in the concentration of contaminants present and some CMW discharges can be a potential water resource, where the local water demands for industrial, irrigation, and even drinking and domestic uses can be fulfilled by effective utilization (Cidu et al., 2007; Singh, 1994). Mining's impacts on the natural water environment may be observed throughout the life cycle of a mine and even long after mine closure (Younger et al., 2002). The potential impacts of mining on the water environment are: (1) disruption of hydrological pathways; (2) seepage of contaminated leachates into aquifers; (3) disposal of CMW, and; (4) depression of the water table around the dewatered zone. Disposal of CMW is a worldwide problem, at both underground and opencast workings (Pulles et al., 1995). The quality of the CMW depends on a series of geological, hydrological and mining conditions, which vary significantly from mine to mine (Younger et al., 2002). The discharged CMW varies greatly in the concentration of contaminants and in some cases it may even meet the drinking water specifications (Singh et al., 2010). Many times, the discharged CMW as such is not usable and may contain unacceptable levels of heavy metals, toxic anions, organic and biological contaminants (Khan et al., 2005; Gupta, 1999). The CMW resource may act as a potential water source in the water scare mining areas and by adopting a suitable water management strategy and treatment process, the CMW generated during mining operations may be harnessed and utilized to meet the regional water demand for domestic, industrial and irrigation uses (Singh, 1994; Tiwary and Dhar, 1994). The CMW may contain large amounts of suspended and dissolved solids, dirty materials and impurities associated with raw coal and they create serious problems of deterioration of water quality of the river or water bodies into which they are discharged (Ghose, 1999). The Damodar River in Durgapur-Asansol region receives waste waters from steel plant, coke oven and coal based chemical industries besides distilleries and paper mills (Chakraborti, 1994). Regulations of Government of India severely restrict the methods of disposal of the effluent loaded with fine material, usually produced in the form of slurry (Bandopadhyay, 1995).

India supports more than $16 \%$ of the world's population with only $4 \%$ of the world's fresh water resources (Singh, 2003). Although agriculture sector in this country has been major 
user of water, share of water allocated to irrigation is likely to be decreased by $10-15 \%$ in next two decades (CWC, 2000). In this changing scenario, reuse of domestic and industrial waste water in agriculture for irrigating crops appears to be a lucrative option (Rattan et al., 2005; Kumar and Chopra, 2013, 2014; Kumar, 2014). Disposal of waste water to agricultural sites offers an economic alternative to disposal into surface waters and it contributes to nutrient cycling. Effluent wastewater can be used for the restoration of degraded land, and for the growth of vegetation having commercial and environmental value (Dighton and Jones, 1991; Kumar, 2014). The performance of few crops irrigated with waste waters discharged from several sources has been studied by earlier researchers. Foliar damages of landscape trees (Quercus virginiana, Chilopsis linearis, Prunus cerasifera and Pistacia chinensis) irrigated with reclaimed wastewater have been reported by Barnett et al. (1994). For utilization and management of available water resources in mining areas, a baseline water quality data and continuous monitoring of water quality of the mining regions is prerequisite. Though, some information on the aspects of CMW quality and impact of mining activities on water regimes are available for Jharia, Raniganj, West Bokaro, Singrauli, Pench and Neyveli coalfield areas (Mondal et al., 2013). However, till date no work is done on the potential of CMW for irrigation purpose in the study area. The objective of the present investigation is to characterize the CMW and to study of the effects and biochemical changes of CMW and Damodar River water (DRW) on Zea mays L. and soil health.

\section{MATERIALS AND METHODS}

Description of study area: The study carried out in East Bokaro Coalfield, located in the Bokaro district of Jharkhand State. This is the third coalfield from East within the chain of coalfields lying in the Damodar Valley. The Coalfield is one of the major repositories of medium-coking, metallurgical coal in Peninsular Gondwana Basins in India, occupying an area of about 237 sq. Km. The East Bokaro Coalfield lies between $23^{\circ} 45^{\prime} \mathrm{N}$ to $23^{\circ} 50^{\prime} \mathrm{N}$ latitude and $85^{\circ} 30^{\prime} \mathrm{E}$ to $86^{\circ}$ $03^{\prime}$ E longitude. It spreads $65 \mathrm{~km}$ from East to West and 10 to $16 \mathrm{~km}$ from North to South. The East Bokaro coalfield is part of Chhotanagpur Plateau. It is highly undulating and hilly all over the area. The regional slope of the area is towards east and controlled the alignment of the tributaries of Damodar

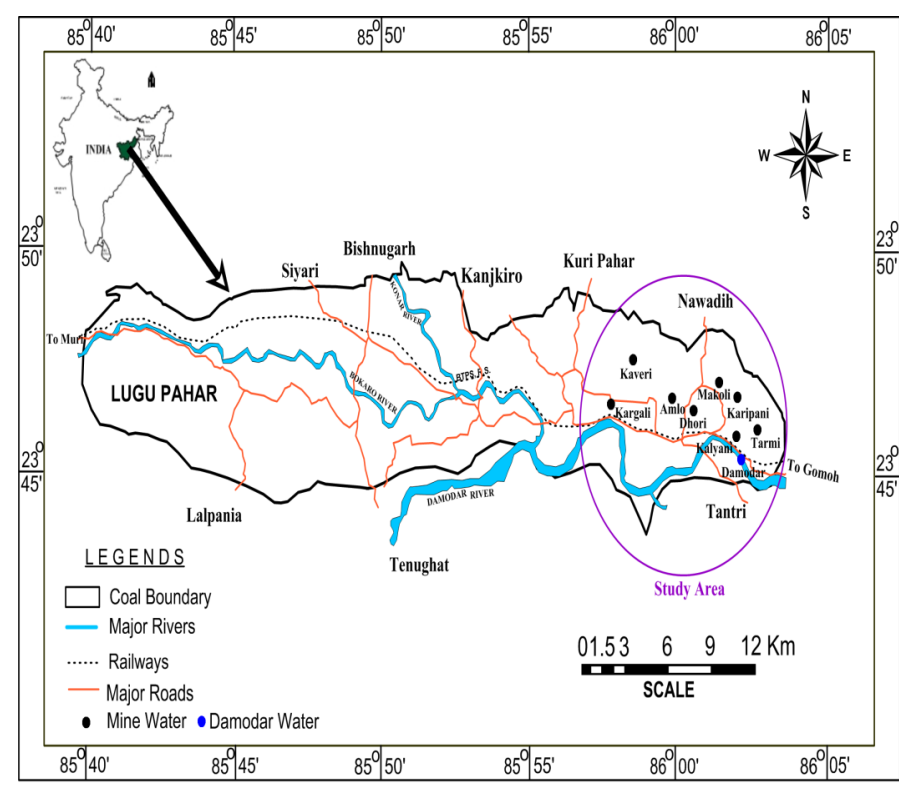

Figure 1. Map of the East Bokaro Coalfield showing the sampling locations.
River. The northern and western part of the area is having hilly ranges. The coalfield is drained by three prominent rivers viz. the Bokaro River in the Central part, the Konar River in the Eastern and the Damodar River in the Southern. The climate of the study area is humid and sub-tropical. It is characterized by hot and dry summer from March to October and cold winter from November to February.

Sampling and analysis of water samples: Coal mine water (CMW) samples were collected during November 2016 from different collieries (viz., Tarmi, Kalyani, Karipani, Makoli, Amlo, Dhori, and Kargali) and composite the samples and Damodar River Water (DRW) was collected from Phusro, near to the coal mining area. The sampling locations are shown in Figure 1. Samples were collected in two litre pre-washed high density polyethylene containers. At the sampling sites, before collecting the samples, bottles were washed with the double distilled water (DDW) and then taken up water samples. Suspended sediments were separated from the water samples in the laboratory by using $0.45 \mu \mathrm{m}$ Millipore membrane filters and preserved $100 \mathrm{ml}$ separately by adjusting the $\mathrm{pH}<2$ with $6 \mathrm{~N}$ ultrapure nitric acid (Radojevic and Bashkin, 1999) for analysis of heavy metal.

Analytical methods: Analysis of collected water samples was done as per Standard Methods (APHA, 2012) for water quality parameters. The $\mathrm{pH}$ and electrical conductivity was measured by using LABINDIA, EC and $\mathrm{pH}$ meter while turbidity of the samples was analyzed by using turbidity meter (EUTECH instruments TN-100). Color was measured as the transmittance at $450 \mathrm{~nm}$ (pc Based Double Beam Spectrophotometer 2202). Total solids including suspended, dissolved and volatile solids were determined using hot air oven at $100^{\circ}$ $\mathrm{C}$ to $105^{\circ} \mathrm{C}$. Dissolved oxygen (DO), bio-chemical oxygen demand (BOD), chemical oxygen demand (COD), chlorides, and alkalinity, total hardness as $\mathrm{CaCO}_{3}$, total nitrogen, sulphate, oil and grease were estimated by following prescribed standard procedures (APHA, 2012). Major anions $\left(\mathrm{F}^{-}, \mathrm{NO}_{3}{ }^{-}\right.$ and $\mathrm{SO}_{4}{ }^{2-}$ were analyzed by $\mathrm{UV}$ Spectrophotometer and $\mathrm{Cl}^{-}$concentration was estimated by titrimetric method. Major cations $\mathrm{Na}^{+}$and $\mathrm{K}^{+}$were estimated by Flame photometer. $\mathrm{Ca}^{2+}$ and $\mathrm{Mg}^{2+}$ concentration were analyzed as $\mathrm{CaCO}_{3}$ by titrimetric method. The concentration of heavy metals in water samples was determined by ICP-MS (Make: Perkin Elmer, Model: ELAN DRCe) at CSIR- Central Institute of Mining and Fuel Research, Dhanbad. Reagent blank determinations were used to correct the instrument readings. For the accuracy of the analysis was checked by analyzing reference standard of water (NIST, 1640a). The precision obtained in most cases was better than $5 \%$ RSD with comparable accuracy.

Pot experiments: The effects of irrigating the soil with CMW and DRW on soil quality and biochemical changes of the plant $Z$. mays L. var. Pioneer at seedling stage were studied in the pot experiment. Stock solutions prepared as CMW +DDW (1:1), CMW (100\%), DRW + DDW (1:1), DRW (100\%) and Control (DDW-100\%) and were used for irrigation of $Z$. mays. These treatments were replicated thrice in a completely randomized design. Germination percentage, shoot length, root length, number of leaves and number of roots of $Z$. mays were recorded. Photosynthetic pigment of $Z$. mays analysis including total chlorophyll, chlorophyll $\mathrm{a}$ and $\mathrm{b}$ was done by following the method (Arnon, 1949). Soil quality parameters like $\mathrm{pH}, \mathrm{EC}$, organic carbon and dehydrogenase activity were estimated by following standard procedures (Tandon, 1995; Chhonkar et al., 2007). 


\section{RESULTS AND DISCUSSION}

Characteristics of CMW and DRW: The results in the Table 1 show that $\mathrm{pH}$ of $\mathrm{CMW}$ was slightly alkaline $(\mathrm{pH}$ 7.98). DRW was more turbid as compared to CMW samples. The electrical conductivity of collected sample of CMW 578 $\mu \mathrm{S} / \mathrm{cm}$ while in Damodar river was observed $218 \mu \mathrm{S} / \mathrm{cm}$. Turbidity is expressed as NTU (Nephelometric turbidity unit). Turbidity of Damodar water was found higher 1.9 NTU. Total solids $(275 \mathrm{mg} / \mathrm{l})$, TSS $(180 \mathrm{mg} / \mathrm{l})$ and TDS $(405 \mathrm{mg} / \mathrm{l})$ were found in CMW. Coals being friable in nature, lots of fines are generated during the coal handling and operation process which increases the TSS in CMW. Oil and grease content was high in CMW $(0.77 \mathrm{mg} / \mathrm{l})$ and Damodar River $(0.22 \mathrm{mg} / \mathrm{l})$. Total nitrogen and phosphorous were very high in Damodar water than CMW. DO content of DRW was higher $(6.3 \mathrm{mg} / \mathrm{l})$ than CMW (5.8 mg/l). BOD was less in CMW $(5.9 \mathrm{mg} / \mathrm{l})$ than DRW $(3.3 \mathrm{mg} / \mathrm{l})$.

The problem of release of metals from coal into water has been reported in earlier studies. The metals reported in coal were $\mathrm{Al}, \mathrm{Ca}, \mathrm{Co}, \mathrm{Cu}, \mathrm{Fe}, \mathrm{Mg}, \mathrm{Mn}, \mathrm{Ni}, \mathrm{Pb}$ and $\mathrm{Zn}$ and the order of leaching rate was $\mathrm{Mn}>\mathrm{Ca}>\mathrm{Mg}>\mathrm{Zn}>\mathrm{Pb}>\mathrm{Fe}>\mathrm{Ni}>\mathrm{Cu}>\mathrm{Co}>\mathrm{Al}$ (Vlado, 1983). In the present study, amongst the parameters analyzed, the maximum value was observed for $\mathrm{Fe}=224.2$ $\mu \mathrm{g} / \mathrm{l}$ in CMW followed by $188.4 \mu \mathrm{g} / \mathrm{l}$ in Damodar water. Na, $\mathrm{K}, \mathrm{Ca}$ and $\mathrm{Mg}$ present in coal have also been found to dissolve in water (Orhan, 1994). Thus, $\mathrm{Ca}, \mathrm{Mg}, \mathrm{Na}$ and $\mathrm{K}$ were high in CMW (Table 1). Chlorine is probably both organically and inorganically bound to coal (Swaine, 1990). The chloride content was high in CMW (15.7 mg/l). Among all parameters, only the TSS of CMW (180 mg/l) and Damodar River (102 $\mathrm{mg} / \mathrm{l})$ exceeds the prescribed limit $(100 \mathrm{mg} / \mathrm{l})$ for industrial effluents, rest all are well within the prescribed limits.

Impact of CMW and DRW on plant and soil health: During the present study, cent percent germination of $Z$. mays was observed in all treatments which revealed that plant can establish in soils irrigated with CMW (Table 2). In line with germination percentage, plant shoot and root length of $Z$. mays was more in CMW than control (double distilled water). The enhanced growth of $Z$. mays was observed in present study is probably due to the nutrients added from CMW. In contrast to present study found that germination of wheat was not affected by the mine effluent (Kaushik et al., 1996), while Kumar (2014) reported that the concentrations (up to 50\%) supported the seed germination of $Z$. mays. However, the seedling growth of wheat was reduced significantly by the effluent in aqueous medium, but not in soil. Effluent water from oil and detergent factories exhibited significant inhibition on shoot growth but root growth was significantly enhanced in sunflower. The number of leaves, number of roots, root and shoot length of $Z$. mays was significantly lower in $100 \%$

Table 1. Characteristics of CMW and DRW of east Bokaro coalfield.

\begin{tabular}{|c|c|c|c|}
\hline Parameters & CMW & DRW & BIS Effluent irrigation standard (2010) \\
\hline $\mathrm{pH}$ & 7.98 & 8.31 & $5.5-9$ \\
\hline Temperature $\left({ }^{\circ} \mathrm{C}\right)$ & 27 & 29.4 & - \\
\hline Electrical Conductivity $(\mu \mathrm{S} / \mathrm{cm})$ & 578 & 218 & - \\
\hline Turbidity (NTU) & 0.75 & 1.9 & 5 \\
\hline Colour (T $450 \mathrm{~nm}$ ) & 90.5 & 89 & - \\
\hline Total solids (mg/l) & 275 & 240 & - \\
\hline TSS (mg/l) & 180 & 108 & 100 \\
\hline TDS (mg/l) & 405 & 152 & 2,100 \\
\hline Alkalinity (bicarbonate) $(\mathrm{mg} / \mathrm{l})$ & 132 & 92 & - \\
\hline Total hardness (mg/l) & 347.8 & 114 & - \\
\hline $\mathrm{F}^{-}(\mathrm{mg} / \mathrm{l})$ & 0.73 & 0.61 & - \\
\hline $\mathrm{Cl}^{-}(\mathrm{mg} / \mathrm{l})$ & 15.7 & 6.7 & 1,000 \\
\hline $\mathrm{NO}_{3^{-}}(\mathrm{mg} / \mathrm{l})$ & 23.6 & 24.2 & -- \\
\hline $\mathrm{HCO}_{3}^{-}(\mathrm{mg} / \mathrm{l})$ & 140.1 & 82 & -- \\
\hline $\mathrm{SO}_{4}{ }^{2-}(\mathrm{mg} / \mathrm{l})$ & 191 & 29.1 & 1,000 \\
\hline $\mathrm{Ca}^{2+}(\mathrm{mg} / \mathrm{l})$ & 59.4 & 32.6 & - \\
\hline $\mathrm{Mg}^{2+}(\mathrm{mg} / \mathrm{l})$ & 48.5 & 7.8 & - \\
\hline $\mathrm{Na}^{+}(\mathrm{mg} / \mathrm{l})$ & 17 & 12.3 & - \\
\hline $\mathrm{K}^{+}(\mathrm{mg} / \mathrm{l})$ & 6 & 1.62 & - \\
\hline Oil and grease $(\mathrm{mg} / \mathrm{l})$ & 0.77 & 0.22 & 10 \\
\hline Total nitrogen $(\mathrm{mg} / \mathrm{l})$ & 0.31 & 12.95 & 100 \\
\hline Phosphorous (mg/l) & 0.0007 & 0.00034 & 5 \\
\hline $\mathrm{DO}(\mathrm{mg} / \mathrm{l})$ & 5.8 & 6.3 & - \\
\hline BOD (mg/l) & 1.3 & 3.1 & 30 \\
\hline COD (mg/l) & 5.9 & 3.3 & 250 \\
\hline $\mathrm{Pb}(\mu \mathrm{g} / \mathrm{l})$ & 0.44 & 0.99 & 0.1 \\
\hline $\mathrm{Cd}(\mu \mathrm{g} / \mathrm{l})$ & 0.12 & 0.08 & 2 \\
\hline $\mathrm{Fe}(\mu \mathrm{g} / \mathrm{l})$ & 224.2 & 188.4 & - \\
\hline $\operatorname{Mn}(\mu \mathrm{g} / \mathrm{l})$ & 1.95 & 1.98 & - \\
\hline $\mathrm{Cu}(\mu \mathrm{g} / \mathrm{l})$ & 2.67 & 5.82 & 3 \\
\hline $\mathrm{Zn}(\mu \mathrm{g} / \mathrm{l})$ & 5.06 & 7.69 & 5 \\
\hline $\mathrm{Ni}(\mu \mathrm{g} / \mathrm{l})$ & 8.14 & 1.26 & 3 \\
\hline $\mathrm{Cr}(\mu \mathrm{g} / \mathrm{l})$ & 3.75 & 2.89 & 2 \\
\hline Co $(\mu \mathrm{g} / 1)$ & 0.09 & 0.04 & - \\
\hline
\end{tabular}

Values are the means of three samples; BIS-Bureau of Indian Standards; CMW-Coal mine water; DRW-Damodar river water. 
Table 2. Effect of CMW and DRW on seed germination and the morphology of Z. mays L. var. Pioneer.

\begin{tabular}{llccccc}
\hline S.N. & Treatments & Germination percent & Shoot length (cm) & Root length (cm) & No. of roots & No. of leaves \\
\hline 1 & CMW+DDW (1:1) & 100 & 7.87 & 6.40 & 4.0 & 3.0 \\
2 & CMW (100\%) & 100 & 9.93 & 10.80 & 5.0 & 3.0 \\
3 & DRW+DDW (1:1) & 100 & 9.03 & 19.77 & 6.0 & 3.0 \\
4 & DRW (100\%) & 100 & 7.33 & 25.93 & 4.0 & 4.0 \\
5 & Control (DDW) & 100 & 7.50 & 14.77 & 3.0 \\
\hline
\end{tabular}

CMW: Coal mine water, DRW: Damodar River water, DDW: Double distilled water.

Table 3. Effect of CMW and DRW on the chlorophyll content of Z. mays L. var. Pioneer.

\begin{tabular}{llcc}
\hline S.N. & Treatments & Total chlorophyll (mg/g) & Chlorophyll-a (mg/g) \\
\hline 1 & CMW+DDW (1:1) Chlorophyll-b (mg/g) & 0.64 \\
2 & CMW (100\%) & 1.36 & 0.72 \\
3 & DRW+DDW (1:1) & 1.2 & 0.52 \\
4 & DRW (100\%) & 0.67 & 0.63 \\
5 & Control (DDW) & 0.66 & 0.15 \\
\hline
\end{tabular}

MW: CMW, DR: Damodar River, DW: double distilled water.

Table 4. Impact of CMW and DRW on soil quality parameters.

\begin{tabular}{|c|c|c|c|c|c|}
\hline S.N. & Treatments & $\mathbf{p H}$ & $\mathrm{EC}(\boldsymbol{\mu S} / \mathbf{c m})$ & Organic C (\%) & Dehydrogenase activity ( $\mu \mathrm{g} \mathrm{TPF} / \mathrm{g} / \mathrm{h})$ \\
\hline 1 & CMW+DDW (1:1) & 6.46 & 150 & 2.05 & 12.81 \\
\hline 2 & CMW (100\%) & 6.67 & 173 & 1.58 & 10.85 \\
\hline 3 & DRW+DDW (1:1) & 6.63 & 231 & 1.89 & 12.11 \\
\hline 4 & DRW (100\%) & 6.47 & 218 & 1.15 & 11.15 \\
\hline 5 & Control (DDW) & 6.72 & 223 & 1.88 & 11.78 \\
\hline
\end{tabular}

CMW: Coal mine water, DRW: Damodar River water, DDW: Double distilled water.

CMW than control. CMW has significantly increased the plant growth parameters of Z. mays; diluting the CMW with good quality water is more effective than unmixed CMW. Total chlorophyll, chlorophyll a and b contents of $Z$. mays significantly increased in all the treatments maximum being at Damodar River (50\% dilution) followed by CMW (Table 3). Similarly it was found that the effluent treatment increased the concentrations of various pigments of wheat (Kaushik et al., 1996). Kumar and Chopra $(2013,2014)$ reported that the sugar mill effluent irrigation supports the seedling growth of sorghum and pearl millet. Higher oil content and favorable photosynthesis were observed in mustard crops irrigated with waste water, due to better utilization of nutrients (Aziz et al., 1994). The nutrient content of the effluent was able to maintain good plant growth for most of the tested species (Claudio et al., 2004).

In the present study, the soil quality was studied at 30 days after the treatment with CMW/Damodar water. It is evinced from Table 4 that soil $\mathrm{pH}$ was not affected due to irrigation with CMW. Conductivity was high $(0.231 \mathrm{dS} / \mathrm{m})$ in Damodar water with $50 \%$ treatment and the least was observed at CMW $(0.150 \mathrm{dS} / \mathrm{m})$. Continuous irrigation with untreated paper mill effluent having high EC resulted in the development of sodicity and soluble salts in the soil (Narwal et al., 2006). Similar findings were also reported by (Chonnkar et al., 2000; Raverkar et al., 2000). Organic carbon was high in $50 \%$ of CMW and low in $100 \%$ of Damodar water. Dehydrogenase activity in the soil environment considered to be a major contributor of overall soil microbial activity and soil quality (Masto et al., 2006), was significantly higher in CMW (12.81 $\mu \mathrm{g} \mathrm{TPF} / \mathrm{g} / \mathrm{h}$ ). In general, there was no adverse effect on plant or soil quality by irrigating with CMW. Therefore, dilution of CMW enhanced the plant growth parameters, chlorophyll content of $Z$. mays and soil enzyme activity.

\section{Conclusions}

This study concluded that characterization of CMW and DRW revealed that only total suspended solids of DRW and CMW exceeds the prescribed Indian standards. Mine waters emanating from the coal mines could be used for irrigation. The absolute CMW showed adverse effect on plant chlorophyll content of $Z$. mays and soil enzyme activity while dilution of CMW enhanced the plant growth parameters, chlorophyll content of $Z$. mays and soil enzyme activity. The CMW and DRM could be successfully used for irrigation. Mixing of CMW with DRW may enhance the quality of water. Thus, this study provided the irrigation water availability in the study area. This may be helpful in the future for the sustainable irrigation management of the water resources in these mining areas.

\section{ACKNOWLEDGEMENTS}

The authors are thankful to University Grants Commission, New Delhi, India for UGC-Dr. D.S. Kothari post doctoral fellowship (OT/15-16/0017) for financial support. Analytical support by CSIR, Central Institute of Mining \& Fuel Research, Dhanbad, is gratefully acknowledged.

Open Access: This is open access article distributed under the terms of the Creative Commons Attribution License, which permits unrestricted use, distribution, and reproduction in any medium, provided the original author(s) and the source are credited.

\section{REFERENCES}

APHA (2012). Standard methods for the examination of water and wastewater, 23th edition, Washington D.C.

Arnon, D.I. (1949). Copper enzymes in isolated chloroplasts. 
polyphenoloxidase in Beta vulgaris. Plant Physiology, 24: 1-15.

Aziz, O., Inam, A. and Siddiqi, R.H. (1994). Impact of treated oil refinery effluent on crop productivity and agricultural soils. Indian Journal of Environmental Health, 36: 91.

Bandopadhyay, P. (1995). Impact and abatement of pollution in coal and mineral processing. Dhanbad: Workshop of Mining Environment, ENVIS Center, CME, ISM.

Barnett, J.W., Kerridge, G.J. and Russell, J.M. (1994). Effluent treatment systems for dairy industry. Australian Biotechnology, 4: 26-30.

BIS (2010). Indian standards for drinking water Specification (IS 10500:1991). http://www.scribd.com/doc/35309468/IndianStandard-for-Drinking-Water-as-Per-BIS-Specifications-2010.

Chakraborti, T. (1994). Management of toxic liquid wastes using biotechnological routes, Symposium Environmental Biotechnology, 28-29 March NEERI, Nagpur, pp II 6-1.

Chonnkar, P.K., Datta, S.P., Joshi, H.C. and Pathak, H. (2000). Impact of industrial effluents on soil health and agriculture Indian experience. Part I: distillery and paper mill effluents. Journal of Scientific and Industrial Research, 59: 350-361.

Cidu, R., Biddau, R. and Nieddu, G. (2007). Rebound at Pb-Zn mines hosted in carbonate aquifers: influence on the chemistry of groundwater. Mine Water and Environment, 26:88-101.

Claudio, L., Riccardo, G., Francesco, P.N. and Francesco, F. (2004). Municipal-treated wastewater reuse for plant nurseries irrigation. Water Research, 38(12): 2939-2947.

CWC (2000). Water and related statistics. RK Puram, New Delhi: Information Systems Organization, Water Planning and Organization Wing, Central Water Commission 66, 451.

Dighton, J., Jones, H.E. (1991). The use of roots to test N, P and K deficiency in Eucalyptus nutrition. IUFRO Symposium on Intensive Forestry: The Role of Eucalyptus. (pp. 635-643). Durban, South Africa.

Ghose, M.K. (1999). Sustainable supplies of water for coal washeries in India. The Science of the Total Environment, 229: 217-225.

Gupta, D.C. (1999). Environmental aspects of selected trace elements associated with coal and natural waters of Pench valley coalfield of India and their impact on human health. International Journal of Coal Geology, 40: 133-149.

Kaushik, A., Kadyan, B.R. and Kaushik, C.P. (1996) Sugar mill effluent effects on growth, photosynthetic pigments and nutrient uptake in wheat seedlings in aqueous vs. soil medium. Water, Air \& Soil Pollution, 87: 39-46.

Khan, R., Israili, S.H., Ahmad, H. and Mohan, A. (2005). Heavy metal pollution assessment in surface water bodies and its suitability for irrigation around the Nayevli lignite mines and associated industrial complex, Tamil Nadu, India. Mine Water and Environment, 24: 155-161.

Kumar, V. (2014). Sugar mill effluent utilization in the cultivation of maize (Zea mays L.) in two seasons. Journal of Waste Management, http://dx.doi.org/10.1155/2014/408509

Kumar, V. and Chopra, A.K. (2013). Response of sweet sorghum after fertigation with sugar mill effluent in two seasons. Sugar Tech, 15 (3): 285-299 DOI 10.1007/s12355-013-0226-9.

Kumar, V. and Chopra, A.K. (2014). Pearl millet (Pennisetum
Glaucum L.) response after ferti-Irrigation with sugar mill effluent in two seasons. International Journal of Recycling of Organic Waste in Agriculture, 67: DOI: 10.1007/s40093-014-0067 $-\mathrm{x}$.

Masto, R.E., Chhonkar, P.K., Singh, D. and Patra, A.K. (2006). Changes in soil biological and biochemical characteristics in a long-term field trial on a sub-tropical inceptisol. Soil Biology and Biochemistry, 38: 1577-1582.

Mondal, G.C., Singh, A.K., Singh, T.B., Tewary, B.K. and Sinha, A. (2013). Hydrogeochemistry and quality assessment of mine water of West Bokaro Coalfields, Hazaribag, Jharkhand. India Journal of Materials Science and Engineering A, 3(8): 540-549.

Narwal, R.P., Singh, A. and Dahiya, S.S. (2006). Effect of paper mill effluent's irrigation on soil and plants health- a case study. The 18th World Congress of Soil Science, Philadelphia, USA.

Orhan, Ed Kural (1994). Coal, resources, properties, utilization, pollution (pp.115-125).

Pulles, W., Howie, D., Otto, D. and Easton, J. (1995). A CMW treatment and management in South Africa. Water Research Commission Report No. 7780/96, Pretoria, South Africa.

Radojevic, M. and Bashkin, V.N. (1999). Practical environmental analysis. Royal Chemical Soc Publications, London, pp. 154-155.

Rattan, R.K., Datta, S.P., Chhonkar, P.K., Suribabu, K. and Singh, A.K. (2005). Long-term impact of irrigation with sewage effluents on heavy metal content in soils, crops and groundwater- a case study. Agriculture Ecosystems and Environment, 109: 310-322.

Raverkar, K.P., Ramana, S., Singh, A.B., Biswas, A.K. and Kundu, S. (2000). Impact of post-methanation spent wash (PMS) application on the nursery raising, biochemical parameters of Gliricidia sepium and biological activity of soil. Annuals of Plant and Soil Research, 2: 161-168.

Singh, A.K. (2003). Water resources and their availability. In: Souvenir, National Symposium on Emerging Trends in Agricultural Physics, Indian Society of Agrophysics, New Delhi, 22-24 April 2003, pp. 18-29.

Singh, A.K., Mahato, M., Neogi, B. and Singh, K.K. (2010). Quality assessment of CMW in the Raniganj coalfield area, India. Mine Water and Environment, (29): 248-262.

Singh, G. (1994). Augmentation of underground pumped out water for potable purpose from coal mines of Jharia coalfield. In: Proceedings of 5th International Mine Water Congress, vol 2, Nottingham, UK, pp. 679-689.

Swaine, D.J. (1990). Trace elements in coal. London: Butter-worth (Chapter 9).

Tandon, H.L.S. (1995). Methods of analysis of soils, plants, water and fertilizers. New Delhi: Fertilizer Development and Consultation Organization.

Tiwary, R.K., Dhar, B.B. (1994). Environmental pollution from coal mining activities in Damodar river basin, India, Mine Water and Environment, Vol. 13. June-December pp. 1--0.

Vlado, V. (1983). Trace elements in coal, vol. 1. Boca Raton, FL: CRC Press.

Younger, P., Banwart, S.A. and Hedin, R.S. (2002). Mine Water, Hydrology, Pollution, Remediation, Kluwer Academic Publisher, Dordrecht, the Netherlands, pp. 442. 